\title{
p-Hydroxybenzoic Acid and Kaempferol from Desmodium triquetrum
}

\author{
Elvira Hermawati*, Suzany Dwi Ellita, Lia Dewi Juliawaty, Euis Holisotan Hakim \\ Natural Product Research Group, Faculty of Mathematics and Natural Sciences, Institut Teknologi Bandung, \\ Jalan Ganesha 10, Bandung 40132, Indonesia \\ *E-mail: elvira@chem.itb.ac.id
}

DOI: https://doi.org/10.26874/jkk.v3i1.51

Received: 30 May 2020, Revised: 31 May 2020, Accepted: 31 May 2020, Online: 31 May 2020

\begin{abstract}
Desmodium triquetrum (Fabaceae) is widely distributed in Indonesia and used as herbal medicines for diuretic, hemorrhoids, tonics, and anti-inflammatory. Two known compounds, $p$-hydroxybenzoic acid (1) and kaempferol (2), were isolated from the $\mathrm{MeOH}$ extract of the leaves of Desmodium triquetrum. The structures of isolated compounds were determined based on ${ }^{1} \mathrm{H}$ and ${ }^{13} \mathrm{C}$ NMR data. The $\mathrm{MeOH}$ extract showed very active with $6,5 \mu \mathrm{g} / \mathrm{mL}$ in addition, compound (1) and (2) showed weak cytotoxicity against murine cell leukemia P-388 with $\mathrm{IC}_{50} 55,0$ and $24,7 \mu \mathrm{g} / \mathrm{mL}$, respectively. Compound (1) was the first reported in this species.
\end{abstract}

Keywords: Desmodium triquetrum, kaempferol, $p$-hydroxybenzoic acid

\section{Introduction}

Desmodium triquetrum or known as the synonym Tadehagi triquetrum, is a plant native to China, India, Sri Lanka, Australia and Southeast Asian countries such as Indonesia [1]. D. triquetrum produced significant anti-inflammatory and antioxidant activity, for example the leaves have potent hepatoprotective and antioxidant activities against $\mathrm{CCl}_{4}$-induced liver toxicity [2], besides the chloroform and alcoholic extracts of $D$. triquetrum (L.) was reported have their antibacterial properties [3]. The phytochemistry of the plants has revealed that this species produces diverse secondary metabolites, such as the leaves of this plant contains tannins, alkaloids, flavonoids and the fruits of this plants contains saponin and flavonoids, while the roots contain alkaloids, saponins, flavonoids, tannins $[2,4,5]$.

Some of these compounds from $D$. triquetrum showed various bioactivities, such as flavonoid derivatives, baicalein, naringin and neohesperidin as antioxidant [1] or lignin derivative, adehaginosin reported to have hypoglycemic activity on Hep G2 cells [6]. As a continuation of phytochemical studies, in this paper, we report the isolation of secondary metabolites and preliminary cytotoxic evaluation of the compounds from the leaves of $D$. triquetrum.

\section{Material and Method}

\subsection{General}

${ }^{1} \mathrm{H}$ and ${ }^{13} \mathrm{C}$ NMR spectra were measured at JEOL ECA500 at $500 \mathrm{MHz}\left({ }^{1} \mathrm{H}\right)$ and $125 \mathrm{MHz}$ $\left({ }^{13} \mathrm{C}\right)$. Chemical shifts are given on sigma (ppm) scale with acetone- $d_{6}$ solvent. Vacuum liquid chromatography (VLC) and centrifugal planar chromatography (CPC) were carried out using Merck silica gel $60 \mathrm{GF}_{254}$ art. 7731 and 7749, respectively. For column chromatography, were used silica Sephadex LH-20. Solvents such as $\mathrm{MeOH}$, acetone, EtOAc, and $n$-hexane, for extraction, fractionation, and purification were of technical grades, which were distilled before used, while $\mathrm{CHCl}_{3}$ used in the purification was a proanalysis grade. For thin layer chromatography (TLC) analysis, precoated silica gel plates (Merck Kieselgel60 $\mathrm{GF}_{254} 0.25 \mathrm{~mm}$ thickness) were used, and spots were detected by UV irradiation and spraying with cerium sulfate followed by heating.

\subsection{Plant material dan isolation}

The dried leaves powdered of $D$. triquetrum $(850 \mathrm{~g})$ (collected from Solo, central java in 2005) were macerated with methanol three times (each 24 h) at room temperature. The extract was then evaporated under vacuum to give acetone extract $(81 \mathrm{~g})$. The $\mathrm{MeOH}$ extract was applied to a silica gel vacuum liquid chromatography (VLC) and eluted with $n$-hexane-EtOAc (10:0-0:10, $\mathrm{MeOH})$ 
to give five major fractions (Frs. A-E). Fraction B $(0.7 \mathrm{~g})$ was purified on radial chromatography eluted with $\left.\mathrm{CHCl}_{3}-\mathrm{MeOH}=39: 1\right)$ to give compound (1) $(12 \mathrm{mg})$. Fraction E $(0.7 \mathrm{~g})$ was purified on column chromatography by Sephadex LH-20 eluted methanol to give compound (2) (10 $\mathrm{mg})$.

p-Hydroxybenzoic acid (1): white powder, ${ }^{1} \mathrm{H}$ NMR (aceton-d6, $500 \mathrm{MHz}) \delta_{\mathrm{H}}$ ppm: $7.90(2 \mathrm{H}, d, \mathrm{~J}=7.6$ $\mathrm{Hz}, \mathrm{H}-2$ and $\mathrm{H}-6), 6.91(2 \mathrm{H}, d, \mathrm{~J}=7.6 \mathrm{~Hz}, \mathrm{H}-3$ and H-5). ${ }^{13} \mathrm{C}$ NMR (aceton- $\left.d 6125 \mathrm{MHz}\right) \delta_{\mathrm{C}} \mathrm{ppm}$ : 122.6 (C-1), 132.7 (C-2 dan C-6), 115.9 (C-3 dan C-5), 162.5 (C-4), 167.4 (-COOH).

Kaempferol (2): yellow pale powder, ${ }^{1} \mathrm{H}$ NMR (aceton-d6, $500 \mathrm{MHz}) \delta \mathrm{H}(\mathrm{ppm}): 6.26(1 \mathrm{H}, d, \mathrm{~J}=$ $1.7 \mathrm{~Hz}, \mathrm{H}-6), 6.53(1 \mathrm{H}, d, \mathrm{~J}=1.7 \mathrm{~Hz}, \mathrm{H}-8), 8.15$ $\left(2 \mathrm{H}, \mathrm{d}, \mathrm{J}=8.8 \mathrm{~Hz}, \mathrm{H}-2^{\prime}\right.$ and $\left.6^{\prime}\right)$ and $7.01(2 \mathrm{H}, d, \mathrm{~J}$ $=8.8 \mathrm{~Hz}, \mathrm{H}-$

$3^{\prime}$ and $\left.5^{\prime}\right)$.

\subsection{Cytotoxic assay}

The cytotoxicity assay was conducted according to the method described previously. The $\mathrm{IC}_{50}$ value is the concentration required for $50 \%$ growth inhibition. Each assay and analysis were run in triplicate, averaged, and the results are shown in table 1.

\section{Results and Discussion}<smiles>O=C(O)c1ccc(O)cc1</smiles>

(1)<smiles>O=c1c(O)c(-c2ccc(O)cc2)oc2cc(O)cc(O)c12</smiles>

(2)
Figure 1. Structures of $p$-hydroxybenzoic acid (1) and kaempferol (2) from the leaves of

\section{D. triquetrum}

Compound (1) has a pair of doblet $\delta_{\mathrm{H}} 7.90$ and $6.91 \mathrm{ppm}(2 \mathrm{H})$ in ${ }^{1} \mathrm{H}$ NMR, suggest as psubstitution of aromatic. Also, in ${ }^{13} \mathrm{C}$ NMR the presence of $167.4 \mathrm{ppm}$ as carboxylic acid and four aromatic part (122.6; 132.7; 115,9 and 162.5) showed a comparison of the NMR data with those reported confirmed the structure compound (1) as $p$-Hydroxybenzoic acid [7]. Compound (1) is a part of hydroxybenzoic acid derivatives (HBAs), which are phenolic compounds with a general structure $\mathrm{C}_{6}-\mathrm{C}_{1}$. Four HBAs, including vanillic acid (3-methoxy-4-hydroxy), syringic acid (3,5- dimethoxy-4-hydroxy), protocatechuic acid (3,4dihydroxy) and $p$-hydroxybenzoic acid, are constituents of lignin. In addition, the previous investigation reported the $D$. triquetrum contains a lot of lignin and some other extra complexes such as tannin [1]. Compound (1) can be found from other plant such as Daucus carota, Vitis vinifera, Xanthophyllum rubescens, Pterocarpus santalinus [8] and Camellia oleifera [7]. This compound showed a variety of activities such as antimicrobe [9] nematicidal, antiviral and antiinflammatory $[10,11]$.

Compound (2) has a pair of doblet $\delta_{\mathrm{H}} 6.26$ and $6.53 \mathrm{ppm}$ as meta coupling with $\mathrm{J}=1,7 \mathrm{~Hz}$. Also, $p$-subtitution of aromatic $\delta_{\mathrm{H}} 8.15$ and 7.01 ppm. Comparison of the NMR data [12], compound (2) confirmed as kaempferol. Compound (2) was reported before as compound from $D$. triquetrum by fingerprint analysis using Ultra Performance Liquid Chromatography (UPLC) with photodiode array detector combined with chemometrics methods [13]. It's derivative of compound (2), kaempferol-3-O- $\beta$ - $D$-rutinoside was determined for antihyperlipidemic effect but showed insignificant effect [14].

In preliminary cytotoxic evaluation against murine cell leukemia P-388, the $\mathrm{MeOH}$ extract showed very active with $6,5 \mu \mathrm{g} / \mathrm{mL}$, after fractionation and purification resulted in compound (1) and (2), have been shown weak cytotoxicity.

Table 1. Preliminary cytotoxicity against murine cell leukemia P-388 of compound (1), (2) and $\mathrm{MeOH}$ extract of $D$. triquetrum

\begin{tabular}{cc}
\hline Compound & $\mathrm{IC}_{50}(\mu \mathrm{g} / \mathrm{mL})$ \\
\hline $\mathbf{1}$ & 55,0 \\
$\mathbf{2}$ & 24,7 \\
MeOH extract of $D$. & 6,5 \\
triquetrum & \\
\hline
\end{tabular}

\section{Conclusion}

Two compounds had been isolated from methanol extract of $D$. triquetrum, $p$-hydroxybenzoic acid (1) and kaempferol (2). Compound (1) was the first reported in this species. Even though both compounds exhibited weak cytotoxicity against murine cell leukemia P-388 in preliminary cytotoxic evaluation, but the $\mathrm{MeOH}$ extract showed very active with $6,5 \mu \mathrm{g} / \mathrm{mL}$. This result suggested that $D$. triquetrum still has many potentials since this species reported contained a 
lot of flavonoid and alkaloids derivatives, which commonly possess a broad spectrum of biological activity.

\section{Acknowledgement}

We acknowledge Herbarium Bandungense (SITH), Institut Teknologi Bandung for collecting and identifying the plant sample.

\section{References}

[1] Vedpal, Jayaram U, Wadhwani A, Dhanabal SP. Isolation and characterization of flavonoids from the roots of medicinal plant Tadehagi triquetrum (L.) H.Ohashi. Nat Prod Res. $2019 . \quad: 1-6$. http://dx.doi.org/10.1080/14786419.2018.15 61679

[2] Kalyani GA, Ramesh CK, Krishna V. Hepatoprotective and Antioxidant Activities of Desmodium Triquetrum DC. Indian $J$ Pharm Sci. 2011. 73(4):463-6.

[3] Chit K, Myint W, Thein K, Maw WW, Myint MM, Than A, et al. Cyclic AMP Phosphodiesterase Inhibitory Activity and Chemical Screening of Four Medicinal Plants. Pharm Biol. 2001. 39(3):181-3. http://dx.doi.org/10.1076/phbi.39.3.181.593 2

[4] Jupudi S, Jubie S, Deepika NP, Dhanabal SP. A new pyrimidine alkaloid from the roots of Tadehagi triquetrum (L.) H.Ohashi. Nat Prod Res. $2019 . \quad: 1-8$. http://dx.doi.org/10.1080/14786419.2019.16 34716

[5] Zheng W, Wang SY. Antioxidant Activity and Phenolic Compounds in Selected Herbs. J Agric Food Chem. 2001. 49(11):5165-70. http://dx.doi.org/10.1021/jf010697n

[6] Wu J, Zhang C yun, Zhang T, Zhao D, An N, $\mathrm{Li} \mathrm{Y}$, et al. A new lignan with hypoglycemic activity fromTadehagi triquetrum. Nat Prod Res. 2015.2 29(18):1723-7. http://dx.doi.org/10.1080/14786419.2014.10 03136

[7] Li B, Luo YM. Studies on Chemical Constituents of Camellia oleifera Abel. Chem
J Internet. 2003. 5:20-3.

[8] Khadem S, Marles RJ. Monocyclic phenolic acids; hydroxy- and polyhydroxybenzoic acids: occurrence and recent bioactivity studies. Molecules. 2010. 15(11):7985-8005. https://pubmed.ncbi.nlm.nih.gov/21060304

[9] Cueva C, Moreno-Arribas MV, MartínÁlvarez PJ, Bills G, Vicente MF, Basilio A, et al. Antimicrobial activity of phenolic acids against commensal, probiotic and pathogenic bacteria. Res Microbiol. 2010. 161(5):37282.

http://dx.doi.org/10.1016/j.resmic.2010.04.0 06

[10] Murugan C, Rayappan K, Thangam R, Bhanumathi R, Shanthi K, Vivek R, et al. Hyperbranched Polymers Series Editors: Titles in the Series: Biomacromolecules. 2016 8(9): $1-7$. http://dx.doi.org/10.1016/j.jconrel.2015.12.0 $24 \% 5 \mathrm{Cn}$

[11] A. Flausino O, Dufau L, O. Regasini L, S. Petronio M, H.S. Silva D, Rose T, et al. Alkyl Hydroxybenzoic Acid Derivatives that Inhibit HIV-1 Protease Dimerization. Curr Med Chem. 2012. 19(26):4534-40. http://dx.doi.org/10.2174/092986712803251 557

[12] Hadizadeh F, Khalili N, Hosseinzadeh H, Khair-Aldine R. Kaempferol from Saffron Petals. Iran J Pharm Res. 2003. 2(4):251-2.

[13] Zhang M, Zhao C, Liang X, Ying Y, Han B, Yang B, et al. Fingerprint Analysis of Desmodium Triquetrum L. Based on Ultra Performance Liquid Chromatography with Photodiode Array Detector Combined with Chemometrics Methods. J Chromatogr Sci. 2016/01/19. 2016. 54(5):706-12. https://pubmed.ncbi.nlm.nih.gov/26791345

[14] Wu J, Ma G, Li H, Wu C, Tan Y, Zhang T, et al. Chemical Constituents with Antihyperlipidemic Activities from Desmodium triquetrum. Chinese Herb Med. $2014 . \quad 6(4): 324-7$. http://dx.doi.org/10.1016/s16746384(14)60049-6 
Hermawati, E., et al./J. Kartika Kimia, Mei 2020, 3, (1), 39-42 